\title{
5. The Multidimensional Transformation of the Norwegian Military Profession - From National Duty to Individual Rights
}

\author{
Harald Høiback
}

\section{Background and Analytical Framework}

This volume aims to investigate the ways in which the military profession in the Scandinavian countries has evolved during the last decades following great upheavals in strategic threats and developments in society at large. The main question it seeks to answer is "how has the profession developed to meet these challenges?"

The task of this chapter is to direct that question towards Norway. To what extent has the Norwegian military profession been transformed in the period, and what characterises this transformation?

Naturally, the task of answering this question could be solved in several different ways. The approach I have chosen is comparative. Thus, I first describe the state of the Norwegian military profession in 1995 and 2020, respectively, before drawing comparisons in order to determine what, in fact, has changed, and what has remained the same. 
1995 was chosen as a transitional mid-point between two different challenges for the Norwegian military: homeland defence and out-of-area operations. Precisely half-way between the end of the Cold War in 1989 and the beginning of the long War on Terror in 2001, in 1995 the preliminary transformation of the Norwegian Armed Forces had begun, although political and military will to change was still characterised by reluctance and caution. In 1995, also, operations in the Balkans had given a preparatory taste of what was to come within a few years.

While the military threat was regarded as diminished in 1995, Norway remained connected to a recently re-named and territorially reduced Russia along its north-eastern border. While the territorial aspect of Norwegian defence had almost entirely vanished in the early 2000s, in the sense that military services and branches were now trained and equipped for out-of-area operations (Græger, 2016, p. 109), the tide turned after the Russian annexation of Crimea in 2014, when Norway began to readjust for territorial defence (Forsvarsdepartementet, 2016).

In addition to this "return of geography," Norway has recently also fallen victim to cyberattacks. In October 2020, Norway's Minister of Foreign Affairs, Ine Eriksen Søreide, openly attributed a cyberattack on the Norwegian parliament to Russia (Fausko et al., 2020). It is not customary to accuse another state of unfriendly behaviour on the internet; the episode demonstrated that the Norwegian Armed Forces of the future should be manned and equipped to meet threats in all dimensions, home and abroad.

To answer the question about the extent and nature of transformation in the Norwegian military, the chapter uses textual analysis as its main methodology. The library at the Norwegian Armed Forces Museums contains a wide range of documents from the seventeenth century to the present, including (among others) formal white papers, regulations, books, articles, flyers, brochures and personal diaries. Consequently, the library provides ample opportunities to paint a rather detailed picture of the Norwegian military profession in 1995 and 2020. The collection's heterogeneity enables one to look at sources unrestricted to those most politically polished.

The key concept of this undertaking is the concept of "profession." The term can be defined in several different ways, and I have chosen here to use Samuel Huntington's classic definition (Huntington, 1957); while it is not entirely flawless, it is well established, particularly in military discourse. The aim here is not to investigate developments in our understanding of the concept of profession, but to investigate changes in the Norwegian Armed Forces. The idea is thus to present two snapshots of the Norwegian military, in 1995 and in 2020 respectively, and then to assess them through the analytical lens of Huntington's definition of the military profession. 
My approach is, therefore, not that of the social scientist, but, rather, that of the historian. The difference is crucial. For a social scientist, the method used in the investigation will determine one's findings. For a historian, the conclusions are the result of a meeting between the historian's perspective and the source material. Two social scientists using the same method to solve the same problem will, ideally, reach the same conclusion. Two historians approaching the same problem, will, ideally, reach two different conclusions - or at least write two different books.

\section{Military Profession - Defined}

Published in 1957, Huntington's The Soldier and the State: The Theory and Politics of Civil-Military Relations soon became a classic within the academic field of civil-military relations and the military profession. Arguably, Huntington's book acquired this status more for its pioneering novelty than for its balanced academic disinterestedness and historical thoroughness, and it is important to note that its definition of profession is not universally shared. The reason I use Huntington here is not that his definition cannot be improved, or that it remains the most up-to-date. Far from it; it is on account of its familiarity (Hosar, 2014, p. 394).

For Huntington, there are three "distinguishing characteristics of a profession as a special type of vocation"; these are "its expertise, responsibility, and corporateness." The expertise of a "professional man is [his] specialized knowledge and skill in a significant field of human endeavour ... acquired only by prolonged education and experience" (Huntington, 1957, p. 8). Professional knowledge has two levels, roughly speaking, one regarding the knowing how, the other the knowing why.

The professional man's responsibility follows from his not working primarily for profit, or for certain clients, but for society as a whole: "Financial remuneration cannot be the primary aim of the professional man qua professional man" (Huntington, 1957, p. 9). Finally, he explains corporateness as the feeling of belonging shared by members of a profession in the "consciousness of themselves as a group apart from laymen" (Huntington, 1957, p. 10).

These characteristics are common to all professions such as law and medicine. What is special for the military profession is that the field of expertise in question is the management of violence (Huntington, 1957, p. 11); the profession's specific responsibility is "the military security of his client, society" (Huntington, 1957, p. 15). Professional corporateness, meanwhile, is shown through the fact that "appointments to rank are normally made by the officer corps itself applying general principles established by the state" (Huntington, 1957, p. 17).

In the following sections, I will use Huntington's insights to describe the military profession as it was in Norway in 1995 and 2020, respectively. What overall 
image of military expertise, the armed forces' feeling of responsibility, and corporateness do the texts from those two years seem to represent? As will be clear, all three have undergone tremendous transformation.

\section{The Norwegian Military Profession in 1995}

In 1995 Norway enjoyed a peacetime force of approximately 34,000, which included 21,000 conscripts. In addition came 12,000 civilian employees. After full mobilisation, the Norwegian Armed Forces would count approximately 255,000 men and women.

The command structure had four main building blocks: the Ministry of Defence $(\mathrm{MoD})$, the Chief of Defence (CHOD), and two operational commanders. At the top of the structure was the Ministry of Defence. It served as the minister's secretariat and, in that capacity, generated security and defence policies and prepared guidelines for the activities of the armed forces. Directly under the MoD was the Chief of Defence and his staff. The CHOD had general command over the entire force and had the daily responsibility for the armed forces' activities. On behalf of the CHOD, four inspector generals, one for each service, conducted training and education while three logistics commands conducted logistics and support. The Commander Allied Forces North Norway (COMNORTH), located in Bodø, and the Commander Allied Forces South Norway (COMSONOR) in Stavanger, had operational command and ran current operations in their respective parts of Norway.

The MoD was in central Oslo, while the Chief of Defence, a four-star general, and his staff were located on the outskirts of Oslo. While the MoD had approximately 200 employees, the CHOD's Defence Staff, which included the four inspector generals stationed in the same HQ, had about 1,000 employees.

In 1995 Norway had no regular Non-Commissioned Officers (NCO). In principle, you were thus either a conscript, serving approximately one year of compulsory service, or an officer. In order to become an officer, however, you had, as a rule, to apply for one of the approximately 15 different Non-Commissioned Officer schools spread around Norway belonging to different services and branches. After a year of basic drill and military leadership training, usually, prospective officers served a compulsory year as a sergeant, usually under some form of supervision. They then either quit the armed forces and went into the mobilisation force as a reservist, or applied for the military academy to become an officer. Those wanting a military career, as a rule, thus had to apply for one of the three military academies.

In 1995, the Army went from two academies to a single institution; from 1996, therefore, each of the three services was served by a single academy. The Home Guard recruited officers mainly from the Army Academy. Education at 
the military academy consisted of two stages, each of two years. Notwithstanding some local differences, approximately half of those that took stage one later continued to stage two.

The highest military education was provided by the staff colleges and was also divided into two stages: Staff College I provided basic staff education and lasted approximately three months, while Staff College II lasted for approximately a year. In 1995, the three fighting services' staff colleges were merged into one joint armed forces Command and Staff College.

To summarise: The best-educated officers in Norway in the 1990s had between seven and eight years of education, including one year on-the-job-training as a sergeant. In addition, some cadets also went through civilian university courses while the "top-brass" were sent to foreign military academies.

In 1995, Norwegian women were not obliged to perform ordinary military service. If they applied voluntarily for admission, however, all posts and schools in all branches and on all levels were open to both sexes. In principle, women enjoyed the same terms of service and opportunities for advancement as men (Børresen et al., 2004, p. 357).

While the above is, of course, only an outline of the state of the Norwegian Armed Forces in 1995, it is hopefully enough to form the basis for the next stage of this chapter, where we will look at the nation's military through Huntington's three-dimensional lens.

\section{Expertise}

From the latter part of the Cold War into the early 1990s, the Norwegian Armed Forces were one of the biggest in the world relative to the population. In case of a military emergency, Norway could, on paper, mobilise almost $8 \%$ of its population (Sunde, 2016, p. 5). The secret behind the huge number was that the standing armed forces, particularly the army, was not a combat-ready force but a big "soldier factory" converting huge numbers of conscripts into a part-time militia. While most able-bodied males in Norway thus had rudimentary military training, the level of competence was modest, at best. As stated by then-retired Major General Martin Vadset in 1995, the armed forces were not particularly worried that the Norwegian soldiers did not "know war" (Græger, 2016, p. 181). The idea was that, if war came, Norwegian stamina, unwelcoming terrain, the country's rough climate and sheer numbers would compensate for any lack of military skill (Ulriksen, 2001, p. 48). And, after all, the Norwegian Armed Forces' task was not to win the war, but to keep ports and airfields open long enough for American reinforcements to arrive. 
In 1995, while post-Cold War cutbacks had almost halved the Norwegian mobilisation force, the mechanism remained the same. Military competence was spread rather thinly between a huge number of conscripts and reservists.

In the officer corps, the "proper" military profession, the situation was rather different. A well-educated officer was comparably competent to their civilian professional peers, after education of a similar duration to that enjoyed by priests, lawyers and medical doctors (Hosar 2014, p. 396-399). Military instruction was, however, not part of the national education system, and courses from military schools had no comparability in the standards of higher-education qualifications; courses were not measured, for instance, by the European Credit Transfer and Accumulation System (ECTS) or the Credit Accumulation and Transfer Scheme (CATS) along the same lines as civilian courses.

In 1995, some attempts were made to afford parts of military education, at least, civilian recognition, in the sense that diplomas from the military academies could be used as building blocks for a civilian degree. It took, however, nearly ten years before this was accomplished, as we see below.

There were many downsides of not belonging to a recognised meriting system (Forsvarsdepartementet, 2001). You were not, for instance, formally qualified to become a teacher in high school even though you may have had 15 years of relevant experience in educating 19-year-old conscripts, and even, perhaps, a formal education twice as long the other teachers at the school. Your military diploma was not acknowledged in the civilian world.

The upside of not belonging to a recognised meriting system, however, was that the armed forces were free to emphasise topics and traits relevant for the military profession. Physical ability and endurance, strength of character, loyalty and sociability could thus be important aspects of military education, concerns completely irrelevant, if not anathema, to a civilian university campus: for Samuel Huntington, indeed, "the virtues of West Point have been America's vices, and the vices of the military, America's virtues" (Huntington, 1957, p. 466).

All veterans from the Second World War were retired by 1995, and service overseas in UN-led operations such as those in the Middle East was not regarded as particularly militarily relevant. This meant that no one had any combat experience to speak of (Laugen, 2009, p. 48). Professional merits were mainly earned through long and hard military exercises, and through several postings to desolate places, particularly in the northernmost parts of Norway.

To summarise: in 1995, Norwegian military competence was very unevenly distributed; in the lower echelons (outside the profession, so to speak), it was scarce and rudimentary. Higher in the hierarchy, military professionals were relatively well-educated, both compared to their civilian peers and to their military 
peers in other NATO-countries. This competence was not particularly "bookish" in nature, but practical. Simply put, in 1995 the Norwegian Armed Forces consisted of a huge number of military amateurs, led by well educated, if somewhat practically minded, officers.

\section{Responsibility}

If the Norwegian Armed Forces were a rather frail giant, its head, the Chief of Defence and his staff, were both influential and outspoken. This was a legacy from 1940, when the military had been badly prepared for the German attack. To ensure that nothing similar would happen again, the Chief of Defence was empowered to speak his mind publicly, in order to help prevent political neglect of the military.

After 1945 we might envision Norwegian society as resting on two equally important pillars, one political and one military. The fundament of the political pillar was the ballot box and universal voting rights. On top was the king, as the formal figurehead of the government. The fundament of the military pillar was basic military training, and compulsory service for all male citizens. The king sat atop this pillar, too, as a four-star general and the formal figurehead of the armed forces.

Of course, the politicians decided the size and funding of the forces. That these two pillars were rather independent of each other is, however, indicated by a royal decree from 10 June 1949: "Directives for officers, non-commissioned officers and military chiefs in case of an armed attack on Norway." According to this directive "an armed attack is to be regarded as an order for complete and immediate mobilisation all over the country if the King (Government) is rendered powerless by the enemy. Orders to discontinue mobilisation issued in the name of the Government are to be considered false." Furthermore: "Officers and NCOs are to follow these basic principles when planning and conducting the defence of the country:

a) They shall at once offer resistance against an armed attack with all resources at their disposal, and in the shortest possible time put all their efforts into the defence effort; b) They are to offer resistance even if they are left on their own and even if the situation looks difficult or hopeless without regard to enemy threat of reprisals (bombing of towns, etc.), and c) They shall continue to fight regardless of orders issued in the name of the King (Government) or other superior authority if the latter are taken prisoner or in some other way are rendered inoperative" (Royal Decree, 10 June 1949).

In rather blunt language, this decree shows that the armed forces' responsibility in case of war was immense (Royal Decree, 1949). As Thomas Schelling 
(1966, p. 50) stated: "Many governments have had constitutional or informal provisions for increasing the authority of the armed forces in time of emergency, thus possibly shifting government authority in the direction of individuals and organisations whose motives to resist were less doubtful."

Great responsibility rested even on reservists and individuals of low rank. In peacetime, tens of thousands of Norwegian reservists had their service weapons stored at home, with ample ammunition to go with them. The government thus had to trust that they did not sell, lose, or use their service arms criminally or foolishly.

To conclude, in 1995 ordinary people, in the shape of part time soldiers, had a personal stake in the defence of Norway in the sense that they had their weapons stored at home, and they were supposed to defend the nation without waiting for orders to do so.

\section{Corporateness}

After completing their basic military training at a young age, most conscripts would return to civilian life, while also regularly being called in for some military training and rudimentary supplementary education until they were 44 years old.

As a result, the military "corporation" in Norway was huge indeed. All able-bodied men, apart from some conscientious objectors who spent their 18 months of compulsory service in places like nursing homes and kindergartens, were members of the corporation. Norway was quite literally constituted by (male) citizens in arms.

To illustrate the point, the Norwegian term "yrkesoffiser" is illuminating. The closest English translation is "professional officer," but the connotations are very different. In English, the term "professional officer" connotes someone competent and highly skilled. "Yrkesoffiser," on the other hand, denotes a person that stayed on in the armed forces, for whatever reason, while all his peers from boot camp went on to lead civilian lives. And everyone knew that if war came and the government was obligated to mobilise the entire force, the bedrock of that force would not be the yrkesoffiserer, but bankers, teachers, lawyers and drivers, called in from wider society to defend the nation (Ulriksen, 2002, p. 241).

\section{Summarised}

In 1995, the Norwegian Armed Forces were a huge organisation touching civilian society in many ways. Almost everyone had served in the armed forces, or had close relations to people who had personal experience from the military. Many also knew that if war came, they would be called up to fight or would have to 
support the war effort through civilian support to the armed forces, the so-called "total defence," which, in addition to civil defence, also included economic, social, psychological, and later digital, measures to enhance national resilience.

Military expertise was spread thinly, and responsibility rested rather heavily on individuals in the military hierarchy. If the mobilisation bell rang, you had to spring into action, regardless of whether you were told to do so by a superior or not. The feeling of military corporateness was thus not restricted to the professionals, but was strongly and visibly integrated into the national character.

This picture of the Norwegian Armed Forces as "the big friendly giant" has changed, and dramatically so, in the last 25 years, due to three game-changing initiatives. The first was top-down, politically driven and inspired by New Public Management; the next bottom-up, and driven by experiences from the field in Afghanistan; and the last was outside-in and driven by what I, following Murray (2019), understand as the new identity politics.

\section{The Norwegian Military Profession in 2020}

By 2020, Norway's peacetime force was down to approximately 19,000 men and women, 7,000 of whom were conscripts; some 4,000 were civilian employees. It continues to have four main services, the Army, the Air Force, the Navy and the Home Guard; Cyber Defence and Special Operations have been established as equal pillars, albeit without their own academies and uniforms.

Since 1995, the mobilisation force has for all practical purposes been discarded. To put it bluntly, what you get in a time of war is what you see in peace. The Home Guard still has reservists principally tasked with defending vital points in their own region in case of a surprise attack or other crises, but the manoeuvre elements are basically what they are, without any reservists to augment or sustain them. The Norwegian Armed Forces are today, therefore, a rapid reaction force ("innsatsforsvar"), not a homeland defence force ("mobiliseringsforsvar") as in 1995.

Similarly, there have been alterations in the command organisation since 1995. While the MoD is still at the top, in 2003 the Chief of Defence lost his own staff and headquarters and is now physically placed in the same building and corridor as the Minster of Defence (Bogen \& Håkenstad, 2015). The four inspector generals have been re-allocated to different parts of Norway.

The daily business of the military is now run by the Defence staff located in the same quarters as the MoD. In his or her capacity as the minister's main military advisor, CHOD has now to pull human resources from the same pool of clerks as the minister. In 2009, the parliamentary defence committee was also merged with the committee for foreign affairs. 
In 1995, operations and major exercises were led by two regional headquarters, one in the south and one in the north. In 2009, the southern headquarters were closed, leaving all operations in Norway and abroad led from Norwegian Joint Headquarters in the northern municipality of Bodø.

The military educational system in Norway has also seen great upheaval. In 2005, the three academies and the joint staff college became accredited parts of the national educational system. While the military schools are organisationally still part of the military, they now issue bachelor's and master's degrees. In 2018, the entire educational chain across the services was separated from their mother services, and merged into one military college under one commander and dean, but still located in different parts in Norway.

The Non-Commissioned Officer schools, previously the principal gateway for those wanting to become officers, were disbanded in the 2018 reforms. By 2020, there were two main gateways to a military career: applying for a three year bachelor education at one of the three academies, finally graduating as an officer, or serving as an enlisted soldier for a year and then applying for a post as a non-commissioned officer or enlisted personnel making up the "other ranks" (OR).

Until 2015, Norway was the only member of NATO without proper NCOs and other ranks (that is, military personnel who are neither officers nor commissioned officers). That year, the Norwegian Parliament decided to establish a corps of specialists and NCOs before 2020 (Endringer i forsvarspersonelloven m.m., 2015). After the implementation of the new system, $70 \%$ of all military employees will be OR and 30\% officers (OF). Parliament also decided that, from 2015, military service was to be compulsory for women, too (Endringer i vernepliktsloven, 2014). This decision did not arise from military necessity, but from pressure from the youth wings of the national parties prompting their parliamentary mother parties to vote for universal compulsory service as a matter of principle and gender equality. As the parliamentarian Snorre Valen stated in Parliament in June 2013: "This political victory, endorsed by Parliament today, is first and foremost a victory for the youth and the conscripts. It was they who forced it through" (Valen, 2013).

It is of course tempting to see compulsory service for women in the light of the United Nations Security Council Resolution 1325 (S/RES/1325) on women, peace and security of 2000 (UN Security Council, 2000). Snorre Valen (2013) even refers to the resolution in his speech to parliament mentioned above. To prove the connection, however, further explanation is required as to why Norway is the only Western state to take this step; although related to the same questions of equality and security, the correlation between Resolution 1325 and compulsory service for women in Norway should be considered spurious. 
Next, we will consider the Norwegian Armed Forces of 2020 through Huntington's three-dimensional lens.

\section{Expertise}

In 1995, a colonel in the armed forces was just as well educated as his civilian peers in terms of the duration of his training, and was considerably better educated and more experienced than a captain or a sergeant. If this is still the case today, it will not remain so for long.

Today, a colonel - that is, an officer who joined the armed forces in the late 1980s and early 1990s - has received, as a rule, between seven and eight years of formal education. The colonels of 2050 - that is, future officers starting their career today - will have received some four years of formal education. In other words, the officers' civilian peers in the future will not be lawyers or medical doctors, but nurses and schoolteachers.

Moreover, the colonel of today is not necessarily more experienced than his younger colleagues. In clear contrast to the force of 1995, validation is now earned in operations overseas. Many young and mid-level officers have thus notably more real military experience than their bosses. There are, of course, individual differences, as there are Norwegian colonels and generals with numerous deployments and substantial combat experience. The bigger picture is, however, that the military leadership has become, or will become, considerably less well educated than their predecessors. In effect, if the Norwegian Armed Forces of 1995 were composed of numerous, if militarily callow, soldiers led by practically-minded and reasonably well-educated officers, it is now almost the other way around. Competence and credibility are no longer, or at least not to the same extent as they were in 1995, to be found in the biggest corner office.

That the military educational system came under the auspices of the Norwegian Agency for Quality Assurance in Education (NOKUT), was, on paper, a good thing. Every ambitious educational system needs external reference points and impulses in order to improve and stay relevant in a rapidly changed world. With the use of an external measuring rod, however, arrives the danger that the curriculum should be developed to fit the apparatus of assessment rather than to create better products for the customer - in this particular case, operational military chiefs. So, in addition to having only half the formal school education as previous generations of military leaders, more time is filled with somewhat irrelevant topics in order to satisfy the measuring system. This is not a particularly new concern: "Courage, resolution, and the ability to keep one's head are not attributes that may be acquired by sitting behind a university desk, plowing through reading lists and writing papers" (van Creveld, 1990, p. 77). 
It does not have to be this way, of course. The military's need for competence may still be the guiding star, and external evaluations might be important means to ensure the quality of the research and education leading to that competence - but I sense a potential vicious circle here. As the quality of military expertise is reduced, a natural result of cutting time spent in school by half, officers' ability to formulate militarily coherent educational requirements may be reduced with it. The result, as shown in Norway, is that military needs come to rely on the ability of the civilian educational staff to formulate such requirements. As the former commandant of the college Major general Rolf Thomsen (2012) stated: "Norwegian Institute for Defence Studies (IFS) played an important role in working out the application for the accreditation." The reason was simple: "IFS knows education" (Thomsen, 2012). While Thomsen was head of a military school established in 1817 and the civilian IFS had never previously been responsible for education, it was, nonetheless, the IFS that formulated the new program - and, unsurprisingly, ended up with many slots that only they could fill in the curriculum. What IFS thought that the military students needed most were topics that only IFS could provide. In other words, the tail wagged the dog.

It is no longer the commander's need for expertise that sets the pace; it is the academic's need for a research outlet. As stated by the previous commander at the Staff College, Brigadier General Tor Arnt Sandli (2012): "The model became the pretext for a larger Norwegian Institute for defence studies, but is not for the best of the Armed forces." The military profession becomes less and less military as it gradually becomes a paler and weaker version of civilian education.

\section{Responsibility}

NATO's operations in Kosovo in 1999 were a wake-up call for Norwegian politicians. Notwithstanding the still-considerable size of the Norwegian Armed Forces, it had been hard to find anything or anyone to send to the Balkans.

The Army's Immediate Reaction Force, the Telemark Battalion, was, for instance, not quite as immediate as its name might suggest. When the Kosovo Force Commander, General Sir Mike Jackson, was told when the Norwegians would arrive in the theatre, he asked: "What's taking so long? Are they walking? (Egeberg, 2017, p. 143). Furthermore, the Norwegian F-16s had limited ability to operate during darkness and to hit targets on the ground. Many found those shortcomings somewhat worrying given Norway's border with NATO's traditional main antagonist. As the Minister of Defence in 1999, Dag Jostein Fjærvoll later said: "It came as a big surprise. I could not believe it" (Egeberg, 2017, p. 98). Had the entire force been a charade or a Potemkin village during all those years during 
the Cold War? The fallout of these unpleasant discoveries was earth-shattering for the way the Norwegian Armed Forces was led.

Armed with, among other things, principles from Thatcherism and New Public Management (NPM), the government decided to abandon the General Staff and place the Chief of Defence in the Ministry of Defence. Different parts of the military had to buy services from each other, and the politicians did not trust the CHOD enough to let him run his own business.

This move de-militarised the upper echelon of the military, rendering it, today, one of many subfields in the governmental administration. The CHOD can no longer develop coherent military advice without using politically sensitive staffers. The same people working for the Minister work for the CHOD, and it is humanly impossible to say something to one of them without thinking of the reaction of the other. This forms a clear contrast to most other governmental areas in Norway, which are usually governed through a directorate physically and organisationally separated from the relevant ministry. In the military case, the directorate is part of the ministry. It is, to put it metaphorically, like playing chess with yourself; the situation gives rise to a real danger that CHOD is reduced to a political mouthpiece rather than the hard-hitting sparring partner envisaged in Eliot Cohen's ideal of an unequal dialogue in which "both sides expressed their views bluntly, indeed, sometimes offensively, and not once but repeatedly" (Cohen, 2002, p. 209). It is worth mentioning, however, that there are signs that this integrated model is under reconsideration.

Eight years under Boris Yeltsin in the 1990s, meanwhile, had seen Russia become a very pale shadow of its former Soviet self. It had become very difficult to consider the experience of 9 April - the day in 1940 that Nazi Germany unexpectedly attacked Norway - still relevant. In the future, the use of Norwegian military forces should be something decided by normal political procedures, not by a decision made by generals in the dead of night, and backed by the Royal Decree of 10 June 1949.

Since wars were tending to move further and further away from Norwegian shores, parliament also decided to merge the foreign and military affairs committees. The use of military force was now part of foreign policy, no longer a matter of homeland defence or national survival. Those were yesterday's worries.

As a result, in Huntingtonian terms, the military profession's responsibility for Norway's security has gone from very great to genuinely negligible. If the Royal Decree of 10 June 1949 has not been formally discarded, the document's import is dormant. In 2013, for instance, a previous Chief of Defence, General Sverre Diesen, stated unambiguously: "The CHOD does not work for Parliament, nor for the media, but for the government" (Diesen, 2013). To modern ears 
that sounds like common sense knowledge of civil-military relations, and in line with Huntington's principle of objective civilian control:

When the military man receives a legal order from an authorized superior, he does not argue, he does not hesitate, he does not substitute his own views; he obeys instantly. He is judged not by the policies he implements, but rather by the promptness and efficiency with which he carries them out. His goal is to perfect an instrument of obedience: the uses to which that instrument is put are beyond his responsibility. His highest virtue is instrumental not ultimate. (Huntington, 1957, p. 73)

This message is miles away from the Norwegian experience of April 1940. Here the completely unprepared government, instantly shaky, began to send mixed signals in all directions. At Midtskogen on 10 April 1940, the day after the attack, the officer in charge even refused to follow a direct order from the Minister of Foreign Affairs (Ruge, 1989, p. 20). The lessons learned from this we have already encountered. The politicians knew through bitter experience that they may become shaky again and stated in the Decree (Royal Decree, 10 June 1949): "Orders to discontinue mobilisation issued in the name of the government are to be considered false."

Presumably, all previous chiefs of defence, up until Sverre Diesen who took the helm in 2005, would have accepted that while it is indeed politicians who have the final word, there may come a situation where the nation's interests are best served by not listening to the politicians. As, for instance, Colonel Birger Eriksen did when he decided to skip the mandatory warning shot and engaged the unknown battlecruiser that approached his position in April 1940 (Høiback, 2003).

Politicians have the right to be wrong, but not the right to fumble away the nation's sovereignty and constitution. This point was elegantly pinned down by General Douglas MacArthur in his address to the Massachusetts Legislature in July 1951:

I find in existence a new and heretofore unknown and dangerous concept that the members of our armed forces owe primary allegiance or loyalty to those who temporarily exercise the authority of the Executive Branch of Government rather than to the country and its Constitution which they are sworn to defend. No proposition could be more dangerous (Lebow, 1981, p. 289).

You could agree or disagree with MacArthur, of course, but there will always be a potential tension between politicians' desire for re-election and the often-pa- 
rochial military views. A younger colleague of MacArthur, General Maxwell D. Taylor, also put his finger on the challenge: "Taylor disapproved of the president's expectation that military officers mould their advice to the views and feelings of superiors and accept public responsibility for policy decisions that they opposed" (McMaster 1997, p. 12).

Thoughts like these are beyond the pale in Norway today. Norwegian generals are, in line with Huntington's message, expected to be ambassadors for the government's policy, unless, of course, they are close to retirement, and can speak their mind without fear of retribution. The security of the state is not the generals' responsibility anymore; it is the government's. Today, Norwegian generals would thus follow General John McConnell's assurance to Lyndon B. Johnson: "The general assured the president that, even if he did not have faith in the administration's policies, he 'would still go ahead and carry out his decisions to the best of my ability, and I would see, also, to it that the entire Air Force did the same'." (McMaster 1997, p. 223).

If the generals have lost their old feeling of professional responsibility for the nation's security, something similar happened to the lowest ranks. In 2002, the government decided that reservists should no longer store their military weapons at home, or, if they did, the weapons should be made unserviceable by the removal of vital parts or the use of a lock (Heimevernet, 2014). The key or the vital part should not be in the soldiers' possession, but should be stored separately higher up in the chain of command. The government did not trust the National Guard with functional weapons in peacetime anymore. Or, rather, the military threat to Norway was considered so low that they did not need to trust them any longer. Even at the lowest level, for the conscripts, their sense of responsibility has changed considerably.

All new recruits are issued a handbook that explains all the minute details of military life, including something about responsibility. In the version handed out to the recruits in 1995, written in 1987, we can for instance read that combat is very difficult, and that we have to cooperate in order to succeed: "We have to be cunning and often do without instructions. We have to follow orders swiftly, and just as important is the leader's and the individual's ability to act without orders, if need be." (Forsvarets Overkommando 1987, p. 146).

In the current handbook, issued in 2015, the message is very different: "For a soldier it is important to show courage, and not only in combat. Everything presented so far is about such courage. Most important of all is the courage to speak out loud if something is wrong - whether it is about bullying, sexual harassment, unjustness, or situations where one can be exposed to great danger" (Soldathåndboken, 2015, p. 109). This mindset is very far from that of 1987. The kind of courage 
asked for in 2015 is more relevant to a high school or a summer camp than to a fighting force that may be exposed to great danger indeed as a matter of course.

\section{Corporateness}

Regarding the feeling of corporateness, three important things have happened since 1995. The number of conscripts is reduced, a corps of specialists and NCOs has been established and identity as merit has been reintroduced.

In 1995, approximately two thirds of every cohort of Norwegian men did compulsory military service. In 2020, that number was down to approximately $13 \%$, of which $75 \%$ were men and $25 \%$ were women (Nilssen, 2019). In the near future, most households in Norway will thus not include someone with personal stories to tell from the military, in clear contrast to the situation in 1995. The odds of a future Prime Minister, Minister of Foreign Affairs, Minister of Defence, or members of the relevant parliamentary committees having personal experience from the armed forces is in steep decline. The same goes for journalists and pundits. While it is of course too early to tell what the consequences of this will be in the long term, it will evidently reduce the almost all-embracing feeling of military corporateness in Norway.

The second change in corporateness is connected to the NCOs. In 1995 Norway did not have NCOs in the ordinary sense; the Norwegian military was more egalitarian than most Western militaries in that nearly all full-time military employees were officers. Arguably, this reflects the fact that the distinction between blue collar and white collar workers in Norway also rather blurred, generally speaking. In Norway, blue collar workers are relatively well paid while the professions command relatively modest salaries compared to other Western countries. Consequently, it is not cost-effective to hire employees for the performance of simple tasks alone. The same goes for the military. It is better to hire one person capable of performing both rather sophisticated and rather simple tasks rather than to hire one person for the sophisticated tasks and another for the simple tasks; this is simply too expensive.

Since Norway is a very egalitarian society, it has twice rejected a two-tier officer corps, once in 1930 and again in the mid-seventies. A symptomatic example of the way Norwegian egalitarianism influences the military is the debate caused by the new NCOs regarding who is required to salute who. In the USA and the UK it is obvious that a sergeant salutes a lieutenant, regardless of age and experience. In Norway this is not obvious at all. It feels strange that a 48-year-old sergeant should salute a 22-year-young second lieutenant.

We can attribute Norway's attempt to yet again resist certain previously inviolable customs to all those years spent in Afghanistan. The country's participation 
in Afghanistan was not principally down to the Taliban, nor on behalf of the Afghan people. If was for the sake of our partners in NATO, and the United States in particular. We were not there primarily to solve other people's troubles, but our own - namely, how to stay relevant and how to ensure that future U.S. Presidents will continue to desire to support Norway (The Norwegian Commission on Afghanistan 2016, p. 8). And in order to look good, what was better than looking similar to the Americans?

The compartmentalisation of military employees in Norway into two groups not only splits the military profession in two, but it also reduces it in size by $70 \%$ - at least according to Huntington. Enlisted personnel are not part of the profession:

The enlisted men subordinate to the officer corps are a part of the organizational bureaucracy but not of the professional bureaucracy. The enlisted personnel have neither the intellectual skills nor the professional responsibility of the officer. They are specialists in the application of violence not the management of violence. Their vocation is a trade not a profession. This fundamental difference between the officer corps and the enlisted corps is reflected in the sharp line which is universally drawn between the two in all the military forces of the world (Huntington, 1957, p. 17).

The third substantial change in the corporateness is not related to numbers, either of conscripts or officers, but cuts to the very bone of professionalism. As stated by Huntington:

Professional competence and the professional spirit reached their fullest development in Prussia. ... The central importance of the military schools and the key role of the General Staff gave the Prussian Army an intellectual overcurrent absent from other forces. As one English observer [Lascelles Wraxall] commented sadly in 1859: "The fact that education is the be-all and end-all of the Prussian officer, is a potent lever in causing him to perfect himself in his profession; and the certainty of promotion through merit and not from caprice, sets the whole of the Prussian officers far above those whom we find in the English army." (Huntington, 1957, p. 53).

Of course, $50 \%$ of the Prussian population, the women, did not qualify, regardless of their skills and ability. That is in principle, the same today. Some members of society, among them convicts, foreigners, and disabled people, do not qualify 
for membership in the military profession regardless of their competence. What is significant of Prussia was thus not that any member of Prussian society could become an officer, but that all those who could be officers could also (in principle) rise to a top position, based solely (in principle) on skills and competence.

The principle that your skills are more important than who you are when it comes to promotion, of course, applied similarly to the Norwegian Armed Forces until quite recently. Now, even the military profession in Norway has become victim to a global megatrend. As described by the British journalist Douglas Murray:

"Identity politics," meanwhile, has become the place where social justice finds its caucuses. It atomizes society into different interest groups according to sex (or gender), race, sexual preference and more. It presumes that such characteristics are the main, or only, relevant attributes of their holders and that they bring with them some added bonus. For example (as the American writer Coleman Hughes has put it), the assumption that there is "a heightened moral knowledge" that comes with being black or female or gay. It is the cause of the propensity of people to start questions or statements with "Speaking as a ..." (Murray, 2019, p. 3).

At the time of writing, the most important interest group in military matters in Norway is that related to gender.

Some would perhaps say that at this juncture the reason for introducing gender quotas and compulsory service for women in Norway is not connected to identity, but to skillset. By bringing both sexes into the military in full force, the armed forces will acquire a broader spectrum of competencies. Such an impression is, however, a fallacy.

As stated by Fine, Joel and Rippon: "In most measures of brain and behaviour, the differences between human males and females are much smaller than the difference in height" (Fine, Joel \& Rippon, 2019). In other words, gender is not the dominant factor in determining emotional and cognitive reasoning. That is, the differences are larger within the biological sexes than between the (average) male and female. So, if you want to recruit someone with a particular skillset connected to brain and behaviour, you have to select specifically on those qualities. To select on gender will not be particularly more relevant than selecting on the colour of the hair. This is, of course, not the case when it comes to physical abilities. Strength and endurance are, in clear contrast to brain and behaviour, significantly correlated to gender. If that were not the case, there would be no point in having separate competitions for men and women in sports. 
The question of women in combat roles is not the issue here. People like General Jim Mattis and former Vice President Dick Cheney, none of them particularly "lefties" or famously feminist, recognise that women can do a superb job on the battlefield. As Mattis stated:

In the spirit of keeping our American experiment alive, it will be enough if this book conveys my respect for those men and women who selflessly commit to serving our country - soldiers, sailors, airmen, Coast Guardsmen, and Marines, united in their devotion to our survival as a nation. In the toughest circumstances, they earned my undying respect and admiration. Alongside them I'd do it all again. (Mattis \& West, 2019, p. 270)

Whether you are a man or a woman, black or white, is completely beside the point, as long as you fill the requirements and are professional in what you are doing. No shortcuts offered: "A good map-reading lieutenant is worthless if he can't do pull-ups" (Mattis \& West 2019, p. 2).

Dick Cheney noted the same, especially when he pinned the Silver Star on specialist Monica Brown in 2007. She had been in a convoy in Afghanistan when a vehicle was struck by an improvised explosive device and the unit was attacked by small arms fire. As one of the injured soldiers, Specialist Jack Bodami later testified: "To say she handled herself well would be an understatement. It was amazing to see her keep completely calm and take care of our guys with all that going on around her. Of all the medics we've had with us throughout the year, she was the one I trusted the most." (Cheney \& Cheney, 2011, p. 96). Paradoxically, the army transferred her to another unit after the incident, because regulations prohibited women from participating in combat missions. This was a wakeup call for Cheney:

As a secretary of defense and as vice president, I had supported the ban on women in combat units. Increasingly, though, soldiers like Monica Brown find themselves on the front lines, and her heroism made me think our policy ought to be adjusted. It needs to reflect the changing nature of twenty-first-century war, in which combat and noncombat, frontline and rear, are not always so easy to delineate (Cheney \& Cheney, 2011, p. 497).

It is not only people like Mattis and Cheney who have noticed this. If you know your trade, people don't much care who you are: "Under the intensified profes- 
sionalism of the twenty-first century, performance, not social background, has become primary. Soldiers have developed solidarities with each other through the competent performance of their mutually allotted tasks, out of which they build up dense networks of trust" (King 2019, p. 148).

When the government in Norway states that at least $30 \%$ of all students at the military schools should be women (Setter mål om 30 prosent kvinner, 2019), they are thus, in my mind, undermining this network of trust. Most students gain their position through their skills and competent performance alone; others gain theirs primarily through who they are. That is problematic, to say the least:

So here is the first conundrum of the current presumption on the position of women as opposed to men in our societies. Women are exactly the same as men - as capable, as able, as suited to the same array of tasks. And also better. Exactly how this is the case is ill defined because it is ill thought through. Nevertheless we have decided to embed precisely such ill-thinking as deep into our societies as we can possibly manage (Murray, 2019, p. 81).

Norway's first female flag officer, Vice Admiral Louise Dedichen, takes this logic even further, and states that leaders should be judged on how many women they employ (Holmes, 2019). To outshine your rival for your next promotion, you thus have to appoint even more women than she does. To put it bluntly, the sky is the limit - or, rather, $100 \%$ is the limit. If there is, as Madeleine Albright tells us, a special place in hell for women who don't help each other, the military profession as we know it is gone. Or, correctly speaking, we are back where we started. Instead of an armed force composed of men alone, we have an armed force composed only of women.

I have, obviously, pushed the argument as far as it goes here. Not even Vice Admiral Dedichen would, presumably, prefer an armed force made up of one single gender. The point is, however, to show how slanted the rhetoric has become. To be of a specific gender has become a quality of its own.

\section{Summarised}

If the Norwegian Armed Forces of 1995 were big, "folksy" and perhaps slightly inept, much had changed by 2020 .

In 2020, a rather large share enjoyed personal combat experience, and even more had experience from overseas operations in different capacities. Many had had a taste of what the armed forces are really for. The formal education, on the 
other hand, was cut in half. Despite the more complex security situation in Europe after the Russo-Georgia war in 2008, the Russian annexation of Crimea and the Russo-Ukrainian War in 2014, and despite the constant urge from NATO to increase the national defence expenditure to $2 \%$ of GDP (NATO, 2014), Norway nearly halved its investment in formal military education. Expertise was thus depressed. Today, and going forward, the lowest ranks are smarter and more experienced than before while the brass are likely to have received significantly less education.

Regarding responsibility, both the generals and the unskilled soldiers were put under administration, so to speak. The CHOD is surrounded by civil servants working for the minister of the day, and the grunts can no longer defend their country without first asking someone for the key to their own gun.

Regarding the feeling of corporateness, the armed forces have first been split in two, with $70 \%$ now falling outside the profession. Then it is split again, this time between those who were commissioned according to their competency and those who primarily commissioned because of who they are. This does not mean, of course, that women are militarily incompetent. Far from it. It means that their professional competency is not regarded as solid enough to be measured on its own merit and, therefore, we need quotas.

This may of course seem like a radical conclusion, even provocative to some. But it is, in my mind, impossible to understand the transformations of the Norwegian Armed Forces over the last 25 years without considering how they have become an important arena for gender politics.

\section{Conclusion}

In this chapter we have seen how the Norwegian Armed Forces have changed almost beyond recognition over the last 25 years.

The most important backdrop for the changes was the disappearance of the Soviet Union in the early nineties. Gradually it became apparent that Norway would never again suffer a surprise military attack. The armed forces could therefore be governed like any other sector in the administration, but on a much shorter leash. Unlike, say, the police, the National Health Service and transportation, there is no separation between the political sphere and the daily running of the military. Based on the politicians' experience of the lack of military preparedness in the late ' 90 s, the government does not trust the armed forces with anything but a very tight leash (Høiback, 2020).

Since Norway has not been particularly afraid of fighting a major war for 
some time, the social imperative now has the upper hand to the extent that the functional imperative has little leverage left: "The military institutions of any society are shaped by two forces: a functional imperative stemming from the threats to the society's security and a societal imperative arising from the social forces, ideologies, and institutions dominant within the society" (Huntington, 1957, p. 2). If we believe society to be virtually unthreatened, the functional imperative is very weak indeed. This effect became most conspicuous in Norway when parliament surprisingly decided that military service should be mandatory for women as well as for men. It was surprising because the military needed very few conscripts, and all military jobs were already open for women. The recruitment of conscripts was not a problem. Norway was also alone in our part of the world to make such a step, where most had discarded compulsory service all together.

While the social forces reigned almost supreme in the capital and the national discourse, the situation was almost completely reversed in the barracks and garrisons scattered around Norway. There, battle-proven veterans knew from personal experience how dangerous compromises and political correctness can be in battle.

If the upper echelons were demilitarised, so to speak, the lower echelons were militarised, and even Americanised, in a sense not seen since the Second World War. It all happened, of course, in Afghanistan where Norwegian troops frequently participated in combat and operations resembling war. A whole new breed of young officers returned home with completely different stories to tell to those of their older peers. The professionalism, the gravity and seriousness among the lower levels increased significantly. Not in the sense that the tone became more sombre, or the jokes more salonfähig, but because the education and training became far more deliberate and realistic.

Since the fear of the big war has gone, or has at least been reduced considerably, while the small war on the model of Afghanistan and Libya is very much present, military discourse in Norway has become confused. The force of the societal imperative from above, and the functional imperative from below, became so strong that the Norwegian Armed Forces snapped in two, with the new NCO-corps as a rather peculiar result. One would be excused for thinking that the new Other Ranks-corps are made up of warriors, while the ranks of officers are composed of politically-conscious military bureaucrats. However, the societal imperative cuts across the OFs and ORs as well.

Some would perhaps claim that changes have been so profound since 1957 that Huntington's definition of the military profession is no longer valid. But, as warned in the introduction, the aim here has not been to investigate developments in our understanding of the concept of "profession," but to investigate 
changes in the Norwegian Armed Forces. To that purpose, Huntington's definition has functioned well as a vehicle to see us through this chapter. Whether the vehicle itself needs adjustment or replacement has not been the issue. ${ }^{1}$

Whether or not we have lost something important since 1995 is a question of individual perspective. Some things have improved; others have not. None of this needs to worry us much as long as there is no threat of our sovereignty becoming the stakes in the big war. And that is a good thing indeed. But if Norway should again be forced to defend its own territory, I personally think we are in big trouble. I leave the vindication to Jim Mattis:

Our military exists to deter wars and to win when we fight. We are not a petri dish for social experiments. No one is exempt from studying warfighting and lethality as the dominant metric, and nothing that decreases the lethality of our forces should be forced on a military that will go into harm's way. I have seen no case where weakness promotes the chance for peace (Mattis and West, 2019, p. 236).

The author wants to thank Jens Christian Borrebye Bjering, Paal Sigurd Hilde, Anne Roelsgaard Obling, Geir Pettersen and Duncan Slarke for inspiring and investigative comments to earlier drafts of this chapter.

1 For those reading Norwegian, I would recommend my own article "Det omvendte militærkupp - en studie av militærprofesjonens vekst og fall," Nytt Norsk Tidsskrift, 01/2020 (Volum 37), where I argue that officers no longer constitute a profession in Norway. 
Bogen, O., \& Håkenstad, M. (2015). Balansegang: Forsvarets omstilling etter den kalde Krigen [The reorganisation of defence forces after the Cold War]. Oslo: Dreyers forlag.

Børresen, J., Gjeseth, G. \& Tamnes, R. (2004). Norsk forsvarshistorie bind 5 - Allianseforsvar i endring [The history of Norwegian defence]. Bergen: Eide forlag.

Cheney, D., \& Cheney, L. (2011). In my time: A personal and political memoir. New York: Threshold Edt.

Cohen, E. A. (2002). Supreme command: Soldiers, statesmen, and leadership in wartime New York: The Free Press.

Diesen, S. (2013) «'Bløffer’ ikke om operativ evne». Aftenposten, 7. mai 2013

Directives for officers, non-commissioned officers and military chiefs in case of an armed attack on Norway. Royal Decree - 10 June 1949.

Egeberg, K. (2017). Fredsnasjonen Norge [The Non-belligerant Norway]. Oslo: Kagge Forlag.

Fausko, L., Skjetne, O. L., Elgaaen, V., Holmes, M. C. S., Hjardar, H. K., Hauge, J., Strøm, O. K., \& Hattrem, H. (2020, October 13). Anklager Russland for IT-angrep mot Stortinget: - Vi må si tydelig ifra [Russia accused of cyberattacks against Stortinget: - We must say no very clearly]. VG. Retrieved from https://www.vg.no/nyheter/innenriks/i/R9RqrA/anklager-russland-forit-angrep-mot-stortinget-vi-maa-si-tydelig-ifra

Fine, G., Joel, D., \& Rippon, G. (2019). Eight things you need to know about sex, gender, brains, and behavior: A Guide for academics, journalists, parents, gender diversity advocates, social justice warriors, tweeters, facebookers, and everyone else. The Scholar and Feminist Online, 15(2). Retrieved from http://sfonline.barnard.edu/neurogenderings/eight-things-you-need-to-knowabout-sex-gender-brains-and-behavior-a-guide-for-academics-journalists-parents-gender-diversity-advocates-social-justice-warriors-tweeters-facebookers-and-ever/

Forsvarets Overkommando (1987). Håndbok for soldaten [The soldier's handbook]. Oslo:

Forsvarets Overkommando.

Forsvarets personell- og vernepliktssenter (2015). Soldathåndboken [The soldier's handbook].

Hamar: Forsvarets personell- og vernepliktssenter.

Forsvarsdepartementet (2001). Omleggingen av forsvaret i perioden 2002-2005, Pkt 5.7.1 (St.prp. nr. 45 (2000-2001)). Pkt 5.7.1 Retrieved from St.prp. nr. 45 (2000-2001) - regjeringen.no

Forsvarsdepartementet (2016). Kampkraft og berekraft - Langtidsplan for forsvarssektoren (Prop. 151 S (2015-

2016)). Retrieved from https://www.regjeringen.no/no/dokumenter/prop.-151-s-20152016/ id $2504884 /$ ?ch $=1$

Græger, N. (2016). Norsk forsvarspolitikk: Territorialforsvar og internasjonal innsats, 1990-

2015 [Norwegian defence policy: territorial defence and international operations 1990-2015]. Oslo: Scandinavian Academic Press.

Heimevernet (2014). Ny praksis for våpenlagring [New practice for the storage of weapons]. Retrieved from: https://www.forsvaret.no/heimevernet/aktuelt/arkivsaker-heimevernet/aktuelt/ny-praksis-for-vapenlagring

Holmes, M. C. S. (2019, February 21). Norges første kvinnelige admiral: - Vi må stille krav om økte kvinneandeler [Norways first female admiral: - we need to make demands about the increased hiring of women]. $V G$. Retrieved from https://www.vg.no/nyheter/innenriks/i/3jnjb9/norges-foerste-kvinnelige-admiral-vi-maa-stille-krav-om-oekte-kvinneandeler

Hosar, H. P. (2014). Offiserene [The officers]. In R. Slagstad \& J. Messel (Eds.), Profesjonshistorier (pp.381412 ). Oslo: Pax Forlag.

Huntington, S. (1957). The soldier and the state: The theory and politics of civil-military relations. Cambridge. Ma.: The Belknap Press of Harvard University Press.

Høiback, H. (2003). Command and control in military crisis - Devious decisions. London: Frank Cass.

Høiback, H. (2020). Det omvendte militærkupp - en studie av militærprofesjonens vekst og Fall [The 


\section{References}

reversed military coup - a study of the military profession's rise and fall]. Nytt Norsk Tidsskrift, 37, 34 - 35. DOI: https://doi.org/10.18261/issn.1504- 3053-2020-01-04

King, A. (2019). Women, gender, and close combat roles in the UK: "Sluts," "bitches," and "honorary blokes." In R. Egnell \& M. Alam, (Eds.), Women and gender perspectives in the military - an international comparison (pp. 141-152). Washington, DC: Georgetown University Press.

Laugen, T. H. (2009). Den norske militære profesjonsidentiteten: Kriger, hjemlandsforsvarer og statsansatt tjenestemann [The Norwegian military professional identity: warrior, homeland defender and government official]. In H. Edstrom, N. T. Lunde, \& J. H.

Matlary (Eds.), Krigerkultur i en fredsnasjon: Norsk militerprofesjon i endring (pp. 48 - 72). Oslo: Abstrakt forlag.

Lebow, R. N. (1981). Between peace and war: The nature of international crisis. Baltimore: Johns Hopkins University Press.

Mattis, J., \& West, B. (2019). Call sign chaos: Learning to lead. New York: Random House.

McMaster, H. R. (1997). Dereliction of duty: Lyndon Fohnson, Robert McNamara, the foint Chiefs of Staff, and the lies that led to Vietnam. New York: Harper Perennial.

Murray, D. (2019). The madness of crowds - Gender, race and identity. London: Bloomsbury Publishing. NATO (2014). Wales Summit Declaration Issued by the Heads of State and Government participating in the meeting of the North Atlantic Council in Wales 05 Sep. 2014. Retrieved: https://www.nato.int/cps/en/natohq/official_texts_112964.htm?selectedLocale=en

Nilssen, N. (2019). "Verneplikten i utvikling". Retrieved from https://www.folkogforsvar.no/verneplikten-i-utvikling/

The Norwegian Commission on Afghanistan (2016). A good ally: Norway in Afghanistan 2001-2014 (Official Norwegian Reports NOU 2016, p. 8). Retrieved from https://www.regjeringen.no/ contentassets/09faceca099c4b8bac85ca8495e12d2d/en-gb/pdfs/nou201620160008000engpdfs.pdf

Ruge, O. (1989), Felttoget. Erindringer fra kampene april - juni 1940 [The campaign - memoirs from the war April - June 1940]. Oslo: Aschehoug.

Sandli, T. A. (2012, March ). Flytt mastergradene til krigsskolene! [Move the master's degrees to the military colleges!]. Forsvarets Forum.

Schelling, T. C. (1966). Arms and influence. New Haven: Yale University Press.

Setter mål om 30 prosent kvinner (2019, June 4). Forsvarets forum. Retrieved from https://forsvaretsforum.no/setter-mål-om-30-prosent-kvinner

Stortinget (2014). Endringer i vernepliktsloven og heimevernloven (allmenn verneplikt - verneplikt for kvinner) Prop. 122 L (2013-2014), Innst. 18 L (2014-2015), Lovvedtak 1 (2014-2015)

Stortinget (2015). «Endringer i forsvarspersonelloven m.m. (militærordningen) (Lov-delen) Prop. 111 LS (2014-2015), Innst. 335 L (2014-2015), Lovvedtak 108 (2014-2015).

Sunde, H.I. (2016). «Kald krig-refleksjoner fra en "kald kriger"» ["Cold War - reflections from a 'Cold Warrior"'], Norsk militært tidsskrift nr.4.

Thomsen, R. (2012, April ). Feil, misforståelser og nostalgi [Mistakes, Misunderstandings and Nostalgia]. Forsvarets forum.

Ulriksen, S. (2001). «Den norske forsvarstradisjonen - Del 1: 1905», Internasjonal politikk 59 [1] 2001: 41-63 | ISSN 0020 - 577X

Ulriksen, S. (2002). Den norske forsvarstradisjonen: Militærmakt eller folkeforsvar? [The Norwegian defence tradition: military power or national defence] Oslo: Pax.

UN Security Council (2000). The United Nation's Security Council Resolution 1325 on Women, Peace and Security (Resolution 1325). Retrieved from https://www.un.org/womenwatch/osagi/ wps/\#resolution 
Valen, S. (2013, June 14). Sak nr. 11 - Innstilling fra utenriks- og forsvarskomiteen om Kompetanse for en ny tid. Presented at meeting with Stortinget Friday June 14th 20139 AM, Oslo. Retrieved from https://www.stortinget.no/no/Saker-og-publikasjoner/Publikasjoner/Referater/ Stortinget/2012-2013/130614/11

van Creveld, M. (1990). The training of officers. New York: The Free Press.

\section{Further reading:}

Parsons, T. (1937). Remarks on education and the professions. The International Fournal of Ethics, 47(3), 365-369. Wilson, 7. Q. (1989). Bureaucracy. New York: Basic Books. 